Arab World English Journal (AWEJ) Special Issue on Covid 19 Challenges April 2021 DOI: https://dx.doi.org/10.24093/awej/covid.7

Pp.95-106

\title{
Means of Foreign Language Teaching during Covid-19 Pandemic in Ukraine
}

Nataliia VENZHYNOVYCH

Department of the Ukrainian Language, Faculty of Philology, Uzhhorod National University, Uzhhorod, Ukraine

Corresponding Author: vennata2017@gmail.com

\section{Mykhaylo POLUZHYN}

Department of the Applied Linguistics, Faculty of International Economic Relations,

Uzhhorod National University, Uzhhorod, Ukraine

\section{Veronika BANYOI}

Department of the Ukrainian Language, Faculty of Philology,

Uzhhorod National University, Uzhhorod, Ukraine

\section{Olesya KHARKIVSKA}

Department of the Ukrainian Language, Faculty of Philology, Uzhhorod National University, Uzhhorod, Ukraine

Recived: $3 / 5 / 2021$

Accepted: 4/3/2021

Published: 4/26/2021

\section{Abstract}

The article deals with the description and analysis of the most important methods of foreign language teaching. The authors describe teaching English in Ukraine during the global pandemic caused by the spread of coronavirus disease Covid-19 in early spring 2020. The study aims at reviewing the most important works of Ukrainian and foreign scholars. They describe the most modern methods of teaching English in higher educational institutions of Ukraine. The scholars pay particular attention to the description of the latest English teaching methods, which they use at Uzhhorod National University. The observation process allowed us to summarize information about the features of distance learning at Uzhhorod National University. Analysis and synthesis, induction and deduction, abstraction generalization, and the descriptive method are applied. The study found out the educational process has been reformed in Ukrainian universities by European quality requirements for education: informatizationglobalization of academic space, integration of functions in modern education, establishing Ukrainian universities cooperation with European and Eastern educational institutions in the field of education and research as well as changes in the educational process associated with the rapid spread of Covid-19, which forced the entire civilized world to seek new types of learning, new methods, and tools. During the pandemic, it is vital to provide personality-oriented education. This knowledge provides optimal conditions for the harmonious development of each student. Further research into the latest computer technologies for foreign language teaching may be a prospect.

Keywords: Covid-19 pandemic, information technologies in the educational process, modern methods of teaching foreign languages, Ukraine

Cite as: VENZHYNOVYCH, N., POLUZHYN, M., BANYOI, V., KHARKIVSKA, O. (2021). Means of Foreign Language Teaching during Covid-19 Pandemic in Ukraine. Arab World English Journal (AWEJ) Special Issue on Covid 19 Challenges (1) 95-106. DOI: https://dx.doi.org/10.24093/awej/covid.7 


\section{Introduction}

Teaching means a complex of training aids and technical appliances with the help of which teacher and students intercommunicate. Teaching includes basic categories of methodology. They facilitate the processes of teaching and language acquisition, and make them more effective. The method distinguishes training aids as well as audio-visual and technical aids. Teaching means comprise the content of the typical study-methodological complex, intended for work with a concrete contingent of students under the conditions of a particular profile of teaching. The obligatory components of the complex are a textbook, audio-visual supplement in computer programs, and video films.

At the present stage of development of science, it is safe to say that it is no longer enough to translate from a foreign language and apply this knowledge in practice, using for teaching ordinary textbooks made in print. Today the educational process in Ukrainian universities is being reformed by the European requirements for the quality of education: informatizationglobalization of the educational space, integration of functions in modern education, the establishment of cooperation by Ukrainian universities with European and Eastern educational institutions in the field of teaching and research, international exchanges, etc., as well as changes in the educational process associated with the rapid spread of Covid-19, which forced the entire civilized world to seek new types of learning, new methods, and tools.

Under such conditions, the number of studies, the subject of the use of information technology in the educational process, has increased significantly. Researchers of such as Adami (2020), Akut (2020), Polat (2002), Todorova (2011), Tarnopilsky (2019), and others.

HEIs in Europe and Ukraine as well are turning a university curriculum from the outdated conventional objective (no E-Learning form) to new high-tech contexts of global changes (fully E-Learning). The people are witness of the fact, how the pandemic Covid-19 lockdown caused the necessity of distant learning. (Babelyuk 2020).

\section{Literature Review}

Today it is impossible to imagine the educational process without the use of the World Wide Web. Kolonuto notes that World Wide Web "allows you to go on a virtual journey around the world, participate in international competitions and Olympiads, organize and conduct joint telecommunications projects." (p. 92). The latest tools and capabilities make us independent, allow us not to limit ourselves to space and time, to be in the usual for us in the comfort zone, and it is easier to overcome the psychological barrier that often appears in direct communication. Technical teaching aids provide students with access to non-traditional sources of information, increase the efficiency of independent work. They also provide completely new opportunities for creativity, and implement fundamentally new forms and methods of teaching. Computers significantly expand the capabilities of teachers, contribute to the individualization of learning. They enhance the cognitive activity of students, adapt the learning process to the individual characteristics of students.

"Each participant of the educational process gets the opportunity to work in their mode, to choose a pace at which the material is optimally assimilated. Electronic textbooks, electronic audio, and video tools and teaching materials, have access to and use Internet resources, which contain a huge amount of necessary resources." (Bilichenko, 2019, p. 27). 
Arab World English Journal (AWEJ) Special Issue on Covid 19 Challenges April 2021

Currently, the possibilities of using information resources and technologies in the educational process are almost limitless.

Bilichenko singled out the need to use current conditions of information technology, Internet resources with the possibility of choosing acceptable for each individual. He believes that:

Modern scientific and technical advances make it possible to use the information, and reference materials on electronic media, electronic textbooks, electronic audio, and video tools and teaching materials, access and use Internet resources, which contain a huge amount of necessary resources. (p. 27).

One of the most common means of information technology is

Electronic textbooks - a kind of learning base. Using electronic textbooks (books), students can watch thematic videos, documentaries, and feature films. In the course of practical tasks, you can use multimedia programs, electronic and online dictionaries ("Lingvo," "Multitran," "McMillian On-Line Dictionary," etc.)." (Bilichenko, 2019, p. 27).

The case-study method is worth mentioning (method of solving specific situations). "When students explore and discuss real situations in active communication, they discuss in groups and solve problems prepared by the teacher." (Bilichenko, 2019, p. 28). Many interesting scientific works of Ukrainian and foreign scientists appeared during the spread of coronavirus disease in the spring of 2020. They draw attention to the peculiarities of learning and teaching English in a global pandemic (see, for example, Adami et al, 2020; Akut, 2020; Alyeksyeyeva, Chaiuk, \& Galitska, 2020; Babelyuk, 2019, Babelyuk, Koliasa, Kushlyk, \& Smaglii, 2020; Huang et al, 2020; Katernina, 2020; Khalfan, Batool, \& Shehzad, 2020; Martin, 2020; Sanchez \& Inaki, 2020, etc.).

\section{Methods}

Specific research objectives of the scientific article led to the choice of methods and techniques of analysis. The teachers use a set of generally philosophical and generally scientific methods. In particular, the researchers used empirical and analytical methods: theobservation process allowed to summarize information about the features of distant learning at Uzhhorod National University. At the practical level, they used general procedures such as analysis and synthesis, induction and deduction, abstraction, and generalization. The scholars also applied descriptive method to analyze and systematize the achievements of Ukrainian and foreign researchers in the field of methods of teaching and learning foreign languages, including English. The study suggests the need to move from the absence of e-learning to complete e-learning during the Covid-19 pandemic.

\section{Data Collection Procedures}

The use of multimedia technology in listening classes is particularly productive. Developed presentations in PowerPoint allow you to represent new vocabulary, focus on the features of lexical and grammatical constructions; to systematize the heard information in the form of schemes and tables for training students to make the lecture summary; correctly and logically compose and quickly record the primary information; visualize complex concepts, clearly demonstrate the processes and phenomena referred to in the text. The material significantly expands the capabilities of conventional textbooks due to audio and video, and animation effects. 
Arab World English Journal (AWEJ) Special Issue on Covid 19 Challenges April 2021

Auditory and visual channels of perception are activated, which allows increasing not only the amount of perceived information but also the strength of its assimilation.

Tsepko and Androsiuk (2020) believed that "the methodology of teaching the humanities in Ukrainian higher education institutions is currently undergoing significant transformations. This is especially true of teaching English both as part of a general university course and in English for professional purposes." (p. 39). They distinguish several modern approaches to learning English: multimedia, discursiveness, and online communication, interactive approach, competency approach, stimulating the continuous use of English, and seductiveness, subjectsubjectivity (teacher-student partnership). Multimedia, online communication, and an interactive process, closely intertwined, are almost essential today. Multimedia, according to Тsерко and Androsyuk, can be of two types: 1) aimed at independent student work (watching movies, working with distance learning courses, working with programs for different English lessons); 2) aimed at acquiring foreign language competencies (group review and listening to Englishlanguage materials and their discussion in a mini-group, implementation of individual or group projects and their representation in class, etc.). Online communication is designed to engage discursive markers and is most related to the practice of language use, rather than the ability to translate or retell unrelated text. The interactive approach became especially common in the early 2000s. Still, it was actively updated in the handemic context, as the possibilities of touch panels, whiteboards, projectors, various online platforms are virtually limitless and can completely replace classroom learning (Tsepko \& Androsiuk, 2020).

Smovzhenko's (2014) concept is exciting and perspective, which proposes to involve project learning in the educational process, which consists of the "project goal - the result (article, abstract, report, videos, etc.); subject of information search - step-by-step search with definition of results; analytical work on the collected facts - conclusions - correction, if necessary, further search for information" (p. 246). It identifies the following types of projects: research projects that require a well-thought-out structure, a defined goal, the relevance of the project for all participants, social significance, well-thought-out methods of work; creative projects, which usually do not have a well-thought-out structure, it develops, obeying the interests of project participants; game projects, the system of which remains open until their completion: participants take on specific roles; information projects aimed at collecting information, its analysis and generalization of facts, require a clear structure, opportunities for systematic correction during project activities; practically oriented, which are marked by a clearly defined from the beginning the results of the project participants, focused on the social interests of the participants themselves (newspaper, document, video, play, action program, draft law, reference material, etc.) (Smovzhenko, 2014). The relevance of such projects today is undeniable, because they had prepared them at home. The results reflect using a variety of modern technologies. The teacher himself determines the problems of the project, but most often, students suggest a topic. Accordingly, project tasks involve significant preparatory work for the teacher: it is necessary to think about what language material should be repeated or discuss with students. A vital criterion is the separate work of students, and the priority is to consider the current problem, which requires integrated knowledge to solve it. The project work is under application at all levels of musterning English as a foreign language during distant learning. The results obtained after the application of the project method have theoretical, practical, moral, cognitive significance. 
Romaniuk (2016), describing the current state of e-learning tools in a foreign language, identified a number of the most popular modern distance learning platforms (Moodle, Google Classroom) and online services (LinguaLeo, Lang-8). A detailed analysis of the three dedicated distance learning platforms Moodle, Google Classroom allowed the author to come to the critical conclusion that:

"All of them are suitable for developing foreign language teaching methods, as they have all the functions necessary to effectively develop reading and speaking skills. Listening and writing, and therefore, the choice of one of them will depend entirely on the personal preferences of each teacher." (Romaniuk, 2016, p. 323).

In a pandemic, Ukrainian universities combine traditional forms of online learning with Moodle learning management system technologies. The system provides an opportunity to implement the latest pedagogical, psychological, methodological developments. In the process of studying the courses, "Moodle" serves as a reliable platform for viewing presentations on particular topics of disciplines, testing, self-study of additional theoretical material, performing tasks for independent work, discussing discussion issues on forums, and more. The use of this distant form of learning provides flexibility (the choice of a convenient pace of learning the course material, taking into account the training). Conveniently, that there are no time restrictions for mastering the material. The distance learning system also has more significant opportunities to control the quality of learning, which involves the use of self-control, the absence of psychological barriers.

Currently, teachers apply many recommendations to study the Moodle system in detail. It is worth mentioning the Guidelines for the development of e-learning materials in the Moodle system, edited by Burlutsky (2017). Many interest facts include Methodical recommendations for students of distance learning system of postgraduate education edited by Isaenko (2014), and others as well as work by Ghounane (2020).

The Moodle platform has many advantages. Uzhhorod National University actively used that platform, and the various activities provided by the system have become crucial for conducting foreign language classes in distance learning. This module alows the teacher the opportunity to develop tests containing questions of different types, including multiple-choice, matching, short answer, and numerical. When learning a foreign language, mini-tests are actively used in individual tasks or at the end of the topic. Tests are also a component of testing knowledge during the exam.

\section{Wiki}

Let's focus on the characteristics of some activities in Moodle:

This is a module of so-called active elements, which allows multiple users to work on one document at a time, make changes to it without deleting the previous version. This activity is vital for the joint compilation and editing of a synopsis on a particular topic: each student has the opportunity to add their material, edit existing.The teacher, controlling the activities of participants, has the opportunity to evaluate the activities of each student, to correct mistakes. The action of Wiki, to some extent, reproduces the conditions of teamwork in the audience: in 
real time, you can discuss the discussion aspects of the topic.

Survey

The module Questionnaire allows you to conduct various types of questionnaires for students to check the effectiveness of learning and learning material.

\section{Glossary}

For students of philological specialties, this module is fundamental and necessary, which allows you to place a dictionary of terms for the course. The glossary can be presented in the form of a dictionary ("term - definition"), as well as in the form of a task (students can fill it in themselves with further evaluation of their work). The glossary allows you to represent the definitions related to all course content (the term described in the dictionary automatically becomes a link). This ensures the systematic nature of the studied material. The Glossary component for a foreign language teacher is an essential tool for acquainting students with new vocabulary, checking the learned vocabulary.

\section{Assignment}

This module allows students to set tasks that require training in electronic form, followed by uploading them to the Moodle server. The most common charges are detailed answers to questions, projects, short messages. The system allows you to rate for completed jobs. The teacher used this type of activity during the study of a foreign language to carry out traditional styles of control: written tests, written testing. The teacher writes a response to the student's answer and gives a grade for it, individually advise the student. However, the most critical advantage, we believe, is the ability to create and propose tasks aimed at self-repetition of the studied material.

\section{Poll (Choice)}

The Poll module allows you to ask questions with the ability to choose one correct answer. This module is often using for student voting.

\section{Database}

A powerful tool for creating documents, drawings, tables, diagrams, and the ability to download literature from the course. Students and teachers can fill the database module allows participants to create, maintain and search for sets of specific records of the same type. The teacher defines the structure of the paper as a set of fields. Field types include a check box, radio buttons, a pop-up menu, text areas, URLs, images, and a downloaded file. Working with the database is especially important for the teacher's activities. It helps to create a standard collection of web links, provides access to all components of educational material, which in real-time can replace a library collection of books.

\section{Tests (Quiz)}

It is one of the favorite types of work among students of philology. The system allows you to download tests with one correct answer or with several. Tests are the most effective forms of control testing students' knowledge during distant education. This is the element of the interaction system between teacher and student. Testing is very viral among students because the current survey in the form of tests helps systematize knowledge, structure the material, get grades "here" and "now." This module inables developing tests comprising questions of different 
types, including multiple-choice, matching, short answer, and numerical. The teachers actively used mini-tests in individual tasks or at the end of the topic. Tests are also a component of testing knowledge during the exam.

Lesson

The Lesson module allows you to present the material in content modules, each of which is placed on a separate page and at the end contains questions for students' self-control. This element helps to create conditions for independent study of the topic, to implement a differentiated approach to learning a foreign language.

\section{Forum}

Forum is one of the most common elements of studying the course, which allows students to express their thoughts, ask questions, ask the teacher, discuss with students and the teacher in particular. The Forum module is connected to e-mail, and then the student receives all messages in the forum by e-mail. During the study of a foreign language, the teacher, with the help of this module, solves the current topical issues of various kinds related to the course's study (organizational, problem issues, placement of ads, etc.).

\section{Chat}

The course element is prevalent among university students because communication takes place in real-time. It allows you to ask short questions and get instant answers in text mode. The communication format reproduces the possibilities of communication in the audience. Still, it also has a significant advantage: the chat stores all the conversations, which allows you to return to them if necessary.

The use of activities through the Moodle learning management system helps to increase the point of teachinng and has a positive impact on the effectiveness of learning a foreign language.

The International Economic Relations Faculty of Uzhhorod National University surveyed students on their assessing effective use of various activities on the Moodle platform. Students had the opportunity to choose from five activities in distant learning as an effective tool for processing materials and testing knowledge (self-control). The survey was attended by 258 students in 1-5 courses majoring in "International Economic Relations" and "Philology. Applied Linguistics." The results of the study showed that 122 students (47\%) prefer tests, 64 (25\%) forums, $31(12 \%)$ - Wiki, $27(10 \%)$ - glossary, and 14 students (5\%) would more often performed different types task.

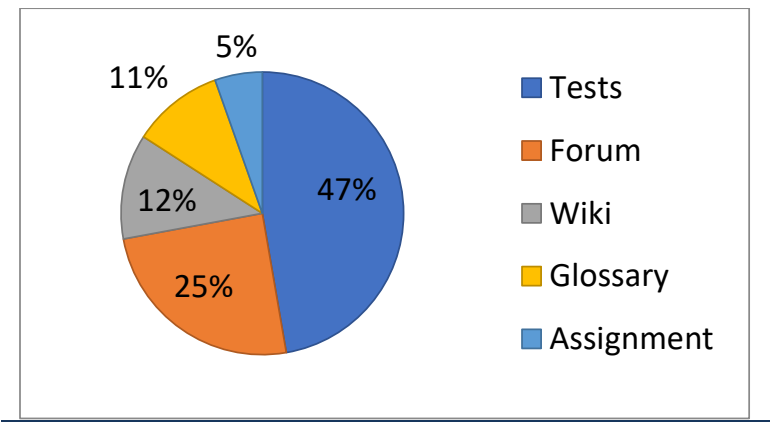


Arab World English Journal (AWEJ) Special Issue on Covid 19 Challenges April 2021

Figure 1. The results of a survey of students to assess different activities on the Moodle platform Moodle platform

Interactive forms of learning, such as group assignments, seminars, and online discussions include web-quests, arouses interest, provides practical orientation, and increases the course's effectiveness.

Of course, the choice of platform and online distance learning tools depends on the teacher. Numerous advantages of online synchronous means of communication, they allow maintaining personal (audiovisual) contact with students. They also create a situation of spontaneous speech, close to the natural environment, provide timely support of voice communication through instant feedback from the audience.

In a pandemic the main tasks are to implement personality-oriented technology, to create optimal conditions for the formation of individual language personality of the student, the development of his communicative competence.

The use of technical means in teaching a foreign language significantly affects the intensity of the educational process. The computer also provides comprehensive control over the learning process. The Internet creates unique opportunities for those who learn a foreign language, allows you to use authentic texts, listen and communicate with native speakers. That creates a natural language environment. Communication through a computer monitor eliminates various negative psychological factors: fear of making a mistake, articulating their thoughts aloud. Such obstacles can prevent the student from showing their actual knowledge. The use of a computer provides many technical specialized possibilities, creates a situation of informal dialogue, and this makes it an essential tool for student-teacher interaction. The newest specialized technologies of training allow to organize independent actions of each student, and the task of the teacher - to provide effective interaction.

The attitude of teachers and students to the lecture as the primary classic type of work in higher education also changed at the beginning of March 2020. During the spread of Covid-19, teachers changed their lecturing approach because the student was tired of sitting in front of the screen for 90 minutes, losing attention and concentration. Thus, a lecture-conversation develops, where 70 minutes the teacher explains new material, students watch videos, and 20 minutes is left to discuss with students. They express their thoughts, visions, discuss, clarify unclear points, and during the lecture can write questions in forums and chats. This lecture must be accompanied by a presentation in MS PowerPoint and posted on the Moodle platform. According to Kukharenko and Bondarenko (2020), "allowed not only to ensure the transition from machine learning to master the skills to acquire new knowledge and skills but also to optimize the educational process." (pp. 172-173).

The approach to conducting seminars, which are mainly aimed at discussing problematic issues, has also changed. Students grouped into micro-groups, made collective decisions, reasonably defended their own opinions, and had the opportunity to present their results on online boards. Such learning is "active, team-based when students interact with classmates and the teacher. It develops divergent thinking, motivates students, they are interested in interaction and achievement of personal and group results" (Kukharenko \& Bondarenko, 2020, p. 173). Of 


\section{Arab World English Journal (AWEJ) Special Issue on Covid 19 Challenges April 2021}

course, the students don't want to turn on the video camera. Then the teacher cannot see the reaction and also does not see if the student is working in a certain period.

The use of interactive forms of learning, such as group assignments, seminars, and online discussions, the use of web-quests, arouses interest, provides practical orientation, and increases the effectiveness of foreign language learning.

\section{Discussion}

The use of technical means in teaching a foreign language significantly affects the intensity of the educational process. The computer also provides comprehensive control over the learning process. The Internet creates unique opportunities for those who learn a foreign language, allows you to use authentic texts, listen and communicate with native speakers. It creates a natural language environment. Communication through a computer monitor eliminates various negative psychological factors: fear of making a mistake, articulating their thoughts aloud. Such obstacles can prevent the student from showing their actual knowledge. By communicating on the computer, the student can get rid of embarrassment and try to show the maximum of their learning. The use of a computer provides many technical possibilities, creates a situation of informal dialogue, and this makes it an essential tool for student-teacher interaction. The newest specialized technologies of training allow to organize separate actions of each student, and the teacher' task - to provide effective interaction.

Uzhhorod National University has developed several educational projects that improve the learning of foreign languages, especially English, in connection with the coronavirus pandemic. Uzhhorod National University published these projects regularly on the official website, at the Media Center, on the web pages of faculties and individual departments. Foreign language training is actively represented on the Zoom and Google Meet platforms. These platforms provide an opportunity for active two-way communication between teachers and students. Foreign lecturers, native speakers of foreign languages studied at Uzhhorod National University, including English, are also invited through electronic communication. The organization of international scientific conferences in the form of distance learning also contributes to improving English language learning due to the limitations associated with Covid19. For example, the International Scientific Conference "Phraseology in the Context of Related Sciences" was held online at the Faculty of Philology of Uzhhorod National University in October 2020, during which researchers delivered their Reports in seven languages, including English. It is valuable that scientists from Ukraine and foreign countries in their research touched, among other problems and issues, on the new terminology that emerged during the coronavirus pandemic. Such reports of scientists combined cognitive and educational factors, and this is extremely important for students.

Uzhhorod National University has joined the "Project to Promote Academic Integrity in Ukraine" (SAIUP) "Honesty Begins with You." In this project, there were meetings with students, heads of courses of all faculties. The aim was to form a group of "agents of influence" who would acquaint their classmates with the principles, basics of academic integrity (students need it when writing term papers, dissertations), disseminate information about it in their faculties, and learn relevant information is essential to learn English language, knowledge of 
which contributes to acquaintance with the experience of foreign countries on this issue in the context of the Covid-19 pandemic.

Uzhhorod National University also successfully selected for the Academic Integrity and Quality of Education Initiative project. The University implemented to the American Councils for International Education with the support of the US Embassy in Ukraine, the Ministry of Education and Science of Ukraine, and the National Agency for Higher Education Quality Assurance. The scholars surveyed 1, 629 students and 429 teachers, and the results of this survey, new methods and tools have been introduced to ensure the quality of education at Uzhhorod National University, in particular during the study of English in a pandemic.

The context of distant education associated with the worldwide distribution of Covid-19, and the priority is technical means of learning: audio, video, and devices for their reproduction, slides, photographs, diagrams, drawings, inscriptions, tables, demonstrated through technological devices, other materials supplied through computers, smartphones, tablets, etc. (Tarnopolsky \& Kabanova, 2019).

\section{Conclusion}

Today, more than ever, distant education has been helped by scientific and technological advances in the computerization of all areas of human activity. Computer technology allows you to solve various educational problems: understanding of language phenomena, formation of linguistic abilities through language and speech exercises, automation of speech and speech actions, creating interesting communication situations. Each multimedia learning tool differs in its originality. Still, it is universal only in the complex application of the latest information technology learning tools, taking into account their characteristics and didactic capabilities. Their use in foreign language teaching will increase the efficiency and quality of the educational process. During the pandemic, it is essential to provide personality-oriented learning. This learning provides optimal conditions for the harmonious development of each student as an individual, a person, the formation of his subjective experience of personal communicative competence, personal growth, and self-realization. Learning interaction involves a partnership of participants in the educational process, based on the ideas of humanism, stimulation of the creativity, and self-realization of both students and teachers, especially in learning foreign languages in difficult times of the global Covid-19 pandemic.

\section{About the Authors:}

Prof. Nataliia Venzhynovych is a Doctor of Philology in Uzhhorod National University. Her research interests include Phraseology, Cognitive Linguistic, Linguoculturology. She is the Head of the Ukrainian Department, the Chairman of the Editorial Board of the Scientific Journal "Scientific Bulletin. Series: Philology." ORCID ID: https://orcid.org/0000-0002-0230-4118

Prof. Mykhaylo Poluzhyn is a Doctor of Philology of Uzhhorod National University, Professor. His research interests include Means of Foreign Language Teaching, Cognitive Linguistic, Linguoculturology, Linguoconceptology. He is the Head of the Applied Linguistics Department. ORCID ID: https://orcid.org/0000-0002-2962-9350 
Arab World English Journal (AWEJ) Special Issue on Covid 19 Challenges April 2021

Veronika Banyoi is a Candidate of Philology ( $\mathrm{PhD}$ in Philology), Associate Professor of the Ukrainian Language Department in Uzhhorod National University. Her scientific interests include Microtoponymy and Dialectology. She is the member in the Editorial Board of the Scientific Journal "Scientific Bulletin. Series: Philology." ORCID ID: https://orcid.org/0000$\underline{0001-7957-8080}$

Olesya Kharkivska is a Candidate of Philology (PhD in Philology), Associate Professor of the Ukrainian Language Department in Uzhhorod National University. Her scientific interests include Dialectology and Deryvatology. She is the member in the Editorial Board of the Scientific Journal "Scientific Bulletin. Series: Philology." ORCID ID: https://orcid.org/0000$\underline{0002-8145-8069}$

\section{References}

Adami, E., et al. (2020). PanMeMic manifesto: Making meaning in the Covid-19 pandemic and the future of social interaction. Working Papers in Urban Language and Literacies no 273. Jul 29, 273. Proceedings of the Research Technologies of Pandemic Coronavirus Impact (RTCOV 2020). Available at: https://www.atlantis- press.com/proceedings/rtcov20/125945666.

Akut, K. (2020). Morphological Analysis of the Neologisms during the COVID-19 Pandemic. International Journal of English Language Studies, 3. 1-7. Retrieved from: https://doi.org/10.32996/ijels.2020.2.3.11.10.

Alyeksyeyeva, I. O., Chaiuk, T.A., \& Galitska, E.A. (2020). Coronaspeak as Key to Coronaculture: Studying New Cultural Practices Through Neologisms. International Journal of English Linguistics, 10(6), 202-212. DOI:

https://www.researchgate.net/deref/http\%3A\%2F\%2Fdx.doi.org\%2F10.5539\%2Fijel.v10 n6p202

Babelyuk, O. A. (2019). Higher Education in Cyber Society: Pros and Cons. Parallels and contrasts: language, culture, communication. Odessa: Phenix, 22-24. Available at: http://dspace.onua.edu.ua/bitstream/handle/11300/12235

Babelyuk, O. A., Koliasa, O. V., Kushlyk, O. P., \& Smaglii, V. M. (2020). Using Distance EdTech for Remote Foreign Language Teaching During the COVID-19 Lockdown in Ukraine. Arab World English Journal. Special Issue on the English Language in Ukrainian Context, 4-15. DOI: https://dx.doi.org/10.24093/awej/elt3.1

Bates, A.W., \& Poole, G. (2003). Effective Teaching with Technology in Higher Education: Foundations for Success. San Francisco: Jossey-Bass/John Wiley.

Bilichenko, A.M. (2019). The Use of Innovative Methods in Practice Activities of a Foreign Language Teacher. An urgent problem of pedagogy, psychology and vocational education, 1, 26-29.

Burlutsky, S.V. (2017). Methodical Recommendations for the Development of Electronic Educational and Methodical Materials in the Moodle DDMA System for Students of all Forms of Education. Kramatorsk.

Ghounane, N. (2020). Moodle or Social Networks: What Alternative Refuge is Appropriate to Algerian EFL Students to Learn during Covid-19 Pandemic. Arab World English Journal, 11(3), 21-41. DOI: https://dx.doi.org/10.24093/awej/vol11no3.2

Huang, R. H., et al. (2020). Handbook on facilitating flexible learning during educational disruption: The Chinese experience maintaining undisrupted education in COVID-19 
outbreak. Smart Learning Institute of Beijing Normal University. Available at: http://www.alecso.org/nsite/images/pdf/1-4-2.pdf

Isaienko, V. M., et al. (2014). Methodical Recommendations for Students of Distance Learning System Postgraduate Education. Kyiv: Dragomanov National Pedagogical University Publishing House.

Katermina, V. V., \& Lipiridi, S. Ch. (2020) Reflection on the Social and Psychological Consequences of the Coronavirus Pandemic in the New Vocabulary of the Nonprofessional English Language Medical Discourse. Proceedings of the Research Technologies of Pandemic Coronavirus Impact (RTCOV), 44-49. Available at: https://www.atlantis- press.com/proceedings/rtcov-20/125945666.

Khalfan, M., Batool, H., \& Shehzad, W. (2020). Covid-19 Neologisms and their Social Use: An Analysis from the Perspective of Linguistic Relativism. Linguistics and Literature Review, 6(2), 117-129.

Kolonuto, D. K. (2014). Modern Technologies in Teaching Foreign Languages. Scientific Bulletin of Uzhhorod University. Series: "Pedagogy. Social work." 92-94.

Kukharenko, V. M., \& Bondarenko, V. V. (2020). Emergency Distance Learning in Ukraine. Kharkiv: Municipal Printing House Publishing.

Martin, A. (2020). How to optimize online learning in the age of coronavirus (COVID-19): A 5point guide for educators. Available at: https://www.researchgate.net/publication/339944395_How_to_Optimize_Online_Learnin $\mathrm{g}$ in the Age_of_Coronavirus_COVID-19_A_5-Point_Guide_for_Educators

Polat, E.S. (2002). New Pedagogical Technologies in Foreign Language Teaching. Foreign languages at school, 1 .

Romaniuk, S.M. (2016). Distance Learning of a Foreign Language: a Comparative Analysis Modern Platforms and Online Services. Bulletin of the Alfred Nobel University of Dnepropetrovsk. Series "Pedagogy and Psychology." Pedagogical sciences. 2016, 1(11), 318-325.

Sanchez, C., \& Inaki, A. (2020). EdTech Knowledge Pack on Remote Learning Response to COVID-19. Available at: http://pubdocs.worldbank.org/en/925611587160522864/KnoweldgePack-COVID19RemoteLearning-LowResource-EdTech

Smovzhenko, L. (2014). Modern Approaches to Teaching Foreign Languages in Higher Educational Institutions. Bulletin of Lviv University. A series of philological, 61, 244-250.

Tarnopolsky, O.B., \& Kabanova, M.R. (2019). Methods of Teaching Foreign Languages and Their Aspects in High School: textbook. Dnipro: Alfred Nobel University.

Todorova, N., \& Bjorn-Andersen, N. (2011). University learning in times of crisis: The role of IT. Accounting Education, 20(6), 597-599. DOI: https://doi.org/10.1080/09639284.2011.632913

Tsepko, T.A., \& Androsiuk, H.L. (2020). Current Trends in Teaching English in the Institutions of Higher Education. Innovative pedagogy, 23 (1) 39-43. 